\title{
Town and Gown in the Orations of Choricius of Gaza
}

\author{
Fotini Hadjittofi
}

\begin{abstract}
This chapter looks at how Choricius represents and 'constructs' his native city, Gaza, as an ideal intellectual space: a privileged city of learning, a peaceful and calm environment in which ideas can be exchanged, and where town and gown not only coexist harmoniously side by side but are also mutually supportive. In his encomiastic orations Choricius places a strong emphasis on the Gazan officials' skills in the non-violent resolution of conflicts, while in Declamation 12 the orator-hero (an idealised version of Choricius himself) appears as the guarantor of the city's well-being and prestige.
\end{abstract}

\section{Introduction}

Choricius, the student and successor of Procopius at the chair of rhetoric in Gaza, has left us a number of works, which can largely be divided into two categories: on the one hand we have encomiastic orations (panegyrics, funeral orations, wedding speeches) for prominent members of Gazan society, and, on the other, a number of declamations, that is, rhetorical exercises or display speeches, closely connected with the activities of the School. ${ }^{1}$ While scholars have mined the first group of orations for historical information on the local landscape, society, and institutions, ${ }^{2}$ the declamations, delivered in a persona different from that of the orator himself, and dealing with mythological and historical themes or with stock questions (based on standardised imaginary scenarios), have so far attracted very little attention, seen as essentially extraneous to contemporary debates. ${ }^{3}$ However, as the cultural movement sometimes called the 'Third Sophistic' is becoming increasingly visible in late antique literary studies, ${ }^{4}$ Choricius is also beginning to receive more attention not only as an important source for the late antique urban and social landscape of Gaza, but also as an educator and a literary artist, who shapes the intellectual and literary landscape of his native city in particular and the Greek East in general. ${ }^{5}$

This chapter will take into consideration works from both categories, aiming to examine how Choricius represents Gaza in the entirety of his oeuvre, not in terms of its physical landscape, but as an ideal intellectual space: a privileged city of learning, a peaceful and calm environment in which ideas can be exchanged, and where town and gown not only coexist 
harmoniously side by side but are also mutually supportive. There would be, of course, significant limitations in attempting to trace the real Gaza in both categories of works: the encomiastic orations are prone to blatant exaggeration, while the declamatory genre posits a fictitious universe, which can only obliquely refer to (or comment on) contemporary reality. The porous boundary separating fact and fiction, historical author and speaking persona (in the declamations) or reality and hyperbole (in the encomiastic orations) frustrates a straightforwardly historicist reading, but at the same time allows us to look beyond historical facts and into the ideology of peace and harmony, galvanised in the School of Gaza. Choricius will be seen to place a strong emphasis on the Gazan officials' skills in the nonviolent resolution of conflicts, with the orator (an ideal version of whom appears in the declamation analysed below) as the natural champion of the reconciliatory power of speech.

Whether or not Choricius' representation of Gaza as a peace-loving city has some basis in historical reality is a moot point; ${ }^{6}$ what is important for the purposes of this chapter is that Choricius considers promoting the values of peace and reconciliation as one of his main duties as the city's leading teacher and orator. This attitude, it will be suggested, is a corollary of his belief that the power of speech (and especially refined, rhetorical speech) and diplomacy is superior and much preferable to military might, and, consequently, that even military men should use persuasion, instead of violence, whenever possible. The orator and teacher of rhetoric thus emerges as a powerful figure himself: a type of hero at the service (and occasionally also the rescue) of his city, and, at least if we believe Choricius' own selfpromotion, the guarantor of his city's well-being and prestige.

\section{Praising Marcian - and all of Gaza}

Two of Choricius' encomiastic speeches, Orations 1 and 2, delivered in praise of Bishop Marcian, have for a long time been studied by literary scholars as well as art historians and archaeologists, since they include lengthy and detailed descriptions of significant urban landmarks. ${ }^{7}$ The first Oration (or First Panegyric for Marcian), delivered in 535-536, praised the Bishop for having constructed or renovated the church of St. Sergius, while the second was delivered some time between 536 and 548 upon the inauguration of the church of St. Stephen. ${ }^{8}$ Apart from providing ekphraseis (that is, detailed descriptions) of the two churches, Choricius mentions a number of other urban features, such as the agora, porticoes, bathhouses, walls, and fortifications - all in connection to his objective of lauding Bishop 
Marcian, credited with either commissioning new edifices or otherwise improving on the built environment of the city. While the information Choricius provides on the physical and urban landscape of Gaza is indeed invaluable, what is significant for the purposes of this chapter is Choricius' construction, in these speeches, of Gaza as the ideal city and its inhabitants as the ideal citizen body. Choricius' classically framed praise of the city, whose urban space is 'updated' and Christianised by its Bishop, endows Gaza with the prestige of the great centres of Hellenism. As Choricius' classical and erudite rhetoric is brought to bear on a landscape that must have looked increasingly un-classical, ${ }^{9}$ the efforts of the rhetor in providing vivid and lasting pictures of the new buildings (and the people who commissioned and used them) ${ }^{10}$ should be seen as parallel to those of the Bishop, although perhaps running to different directions: while Marcian renews and, in a way, modernises Gaza, Choricius invests it with the glory of classical antiquity in language carefully calculated to evoke the glories of the classical past while not conflicting with his audience's Christian beliefs. ${ }^{11}$

An important element in the self-definition of the educated elites in the late antique Greekspeaking world was their sharing in paideia, that is, classical education and culture. While the knowledge and emulation of the classical past is a theme that runs through all of postclassical Greek literature, Gazan authors seem particularly concerned with how they measure up against the glories of classical antiquity, and especially that of democratic Athens. ${ }^{12}$ In a number of passages Choricius compares and contrasts his contemporary, sixth century CE Gaza to fifth century BCE Athens, conceived as the pinnacle of Greek literature, philosophy, and civilisation in general. Perhaps surprisingly for a modern audience, the comparison always works in Gaza's favour. ${ }^{13}$ In the Dialexis, that is, the preliminary talk, which Choricius delivered before his First Panegyric for Marcian, the orator speaks of the festival that has brought all the citizens of Gaza together, and in the context of which they celebrate the new (or renovated) church of St Sergius. What comes naturally to Choricius, as a postclassical man of letters, is to reach back to the classical past and look at how the present festival compares to those of ancient Greece:

Now at Sparta, when the Hyacinthia is celebrated - for the citizens of Sparta honour the youth [Hyacinthus] - a chorus of individuals of the same age as the honourand sing to the accompaniment of lyre and pipe, and maidens dance to the rhythm of the song; for people who live a martial life are not well versed in celebrating by means of oratory. But here, my friends, we follow both the pleasant practices of Sparta and the more lofty 
ones of Attica. We do not imitate the orators of Athens in this respect though: it is not our custom to speak charming deceits to our audiences, but we follow the facts wherever they lead us; among us, anyone who flatters would find himself on the defensive. $^{14}$ (Dialexis 1.4)

In this passage Gaza outbids both of the ancient Greek iconic city-states, Sparta and Athens, which represented two different cultural paradigms. Gaza is superior to Sparta, because Spartans are only soldiers, who do not know how to celebrate with oratory (Choricius' disparagement of the martial life is a theme which will reappear), and it is even superior to Athens, because Gazan oratory is (claimed to be) honest. Choricius' need to validate Gazan intellectual and cultural life through comparison with the classical past is in itself significant, but what is striking here is that Choricius puts Gazan supremacy down to a selection process (as opposed to uncritical emulation), through which Gaza's cultural and intellectual life combines the pleasant practices of the Spartans (dance) with the lofty oratory (but not flattery) of the Athenians. The idea that authors and readers should select elements from within the classical literary tradition which are appropriate - or merely acceptable - in terms of Christian morality is a frequent theme in late antique theoretical discussions on the enjoyment and creation of literature (and echoes of it are found in the First Panegyric for Marcian itself). ${ }^{15}$ It is still remarkable, however, that Gaza should be represented here as having the collective wisdom, as a citizen body, to imitate those aspects of classical Greek lifestyle(s) which are still considered suitable and pleasant, while rejecting what contemporary mores would see as objectionable. The advantageous comparison of Gaza to Athens and Sparta re-emerges within the text of the First Panegyric for Marcian:

Furthermore, in Athens it was considered shameful to walk in festal processions and revel without a mask, and the festivals of the wisest men consisted of obscene jokes for each other; but our [festival] will not need such covering. For we do not show off to each other with impudent tongues, while propriety shines forth in even the most waggish of citizens, so that even if someone appears in the middle of a gathering with a threadbare garment he does not seem to deviate from prescribed behaviour. The Spartans are also said to have celebrated their festivals with decorum, and did not allow anyone to enjoy too much licence on the occasion, on pain of suffering the greatest punishment according to the law. But since propriety is present among us naturally, we do not need the instruction of the law. (Laud. Marc. I 91-2). 
In its obvious exaggeration, Choricius' speech goes beyond praise for the Bishop or even for the city and its new edifices, and advertises the festival and the behaviour of all Gazan citizens. Gazans are collectively declared more decorous than 'the wisest men' (the ancient Athenians) and more self-controlled than the most disciplined Greeks (the ancient Spartans). The Athenian festivals are unacceptable in terms of contemporary morality, because they included obscene jokes (a reference to Old Comedy), ${ }^{16}$ while the decorum of Spartan festivals was, in a way, false or merely superficial, as it was enforced by law. Both ancient Greek paradigms are at least partly rejected, and Gazans are said to prevail, since they have propriety (to semnon / semnotês) as an innate quality, meaning that even in the absence of law (or appropriate clothing!) they are able to self-police their behaviour. ${ }^{17}$ In the Second Panegyric for Marcian the same theme gets a new twist:

The four festivals formerly famous throughout Greece, always presented competitive contest, and divided the spectators among those who were competing and, inciting their hearts to anger, caused irreconcilable animosities. In our festival, though, the quarrelsome contests and the common cries and vulgar dancing appropriate rather to performances of Dionysus, all [these] are shunned. (Laud. Marc. II 70)

Here, the Gazan festival is praised not only for its propriety (in not including vulgar spectacles), ${ }^{18}$ but also for shunning precisely the element that was at the heart of classical Greek festivals: competition. Regarded by Choricius as divisive and disruptive, contests are rejected, since they cause the objectionable emotion of anger, which in turn causes 'irreconcilable animosities'. ${ }^{19}$ As it will be seen later on, for Choricius, very few things are deemed worse than an animosity which is beyond reconciliation. Whether reflecting historical reality or not, Choricius shows that one of the qualities he most values in his city's intellectual and cultural life is its lack of conflict.

\section{Academic life in Gaza according to Choricius}

The values of peace, harmony, and propriety are also at the heart of Choricius' representation of how the Gazan School is run. In the Funeral Oration for Procopius, his old teacher, Choricius claims that disorder and confusion gripped the Athenian assembly when Pericles was absent, 'but at the first sight of his appearance, the assembly was transformed. But you 
would see Procopius' flock retaining the same decorum whether or not Procopius was present, because good conduct had been firmly implanted in them' (Or. 8.6). Again, the Athenian paradigm is crucial, since the excellence of Procopius as a teacher has to be read against the legendary statesman Pericles and his command over the Athenian assembly. And yet again, the Gazan 'assembly' (this time, specifically, Procopius' students) outbids the

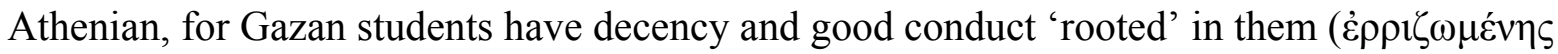

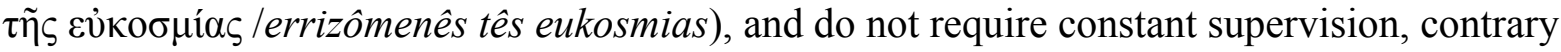
to the Athenian citizens.

Even if we take what Choricius says of the Gazan School with a pinch of salt (as we should, since, after all, this is a funeral eulogy), it is telling that Choricius insists on the students' good conduct and decorum. At the very least, if there had been student riots or brawling on Gaza's streets, Choricius would not be emphasising this aspect. Late Antique 'university cities' in fact often suffered from the antics of disorderly students. Fourth-century Athens is a particularly notorious example: an economically depressed city, whose only world-class industry was its School, attended by wealthy (mostly foreign) students, who would habitually riot through the streets. ${ }^{20}$ Libanius, the famous orator from Antioch who went to Athens to study rhetoric as a young man, mentions in his Autobiography (Or. 1.21) everyday skirmishes and a 'great battle' in which almost all students participated. ${ }^{21}$ The teachers were often involved in, if not motivating, these violent incidents, and they were certainly behind the forcible recruitments of new students immediately upon their arrival - a 'custom' imposed on Libanius himself..$^{22}$ In one of his Letters (Ep. 715.3), Libanius says that he saw many students bearing scars from wounds inflicted in the Lyceum, and opines '[Athenian] teachers hammer out (i.e. educate) soldiers rather than orators'.

Himerius, a contemporary of Libanius and a teacher at Athens, also indicates that brawls and riots had become an expected part of the Athenian student experience, even though he does not seem to approve of the violence. Several of his Orations are addressed to rebellious students, who skip lectures because of their involvement in violent conflicts. ${ }^{23}$ Among these, Oration 16 is significant in that it presents the orator's speech as a drug or remedy, able to eradicate the strife and intense emotions which have taken hold of his students: 'sweet and all-wise speech, which, like a drug, is able to extinguish emotions that swell up from the depths of the heart' (Or. 16.1). Himerius is, in fact, an important precedent for an idea that Choricius also seems to espouse (as it will be argued later on): that oratory has the ability and 
duty to extinguish passions, and that the successful orator (and especially teacher of oratory) should be able to bring an end to conflict. ${ }^{24}$

References to student violence or brawling are entirely absent from Choricius' oeuvre, and, although this does not necessarily mean that Choricius' representation is accurate, it could be significant that in his Dialexeis ('preliminary talks'), which abound in information on school life in Gaza, ${ }^{25}$ the descriptions of incidents happening in- or out-side the classroom often involve dissenting opinions but never open conflict. There is only one episode in which Choricius seems to have felt threatened. In Dialexis 5.4-6 the orator says that his students often asked him to declaim, but he kept postponing his performance because he wanted to gather together the right audience, those 'knowledgeable about eloquence'. At some point, Choricius finds himself surrounded by a crowd of young men asking him insistently to declaim, and each one appearing more eager than the other. ${ }^{26}$ Choricius asks them not to get

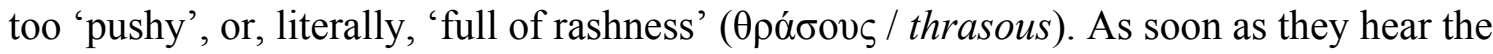
word 'rashness', they elbow each other, whispering, 'This fellow seems to be a coward'. Choricius feels stung by the remark, and decides to present his speech. ${ }^{27}$ This is the most violent behaviour that Gazan students can exhibit, according to the evidence we have in Choricius, and even here the suggestion of violence (or merely rashness) could conceivably be an indication of the students' keenness to listen to and learn from their teacher, thus ultimately reflecting well on Choricius' own skills as a declaimer. ${ }^{28}$

Other incidents described in the Dialexeis show that, occasionally, aspects of Choricius' performances came under criticism, but this was voiced in a more or less civilised way, and Choricius presents himself as addressing all censure successfully. Dialexis 17 introduces the second half of Choricius' Declamation 8, titled 'A Spartan Citizen'. Choricius explains that he was forced to interrupt his performance the previous day, because the speech was too lengthy, and his voice, as he says, 'refused to minister to his zeal'. The audience, which apparently included not only his students but also a 'crowd' of other men, got up in the middle of the speech and left the theatre. ${ }^{29}$ Now Choricius is walking home, and his students escort him, as they usually do, when one of their friends walks up to Choricius, and accuses him of not being laconic while declaiming on a Laconian theme, and of forgetting his Homer, who had praised the Spartan Menelaus for speaking briefly and clearly. ${ }^{30}$ Choricius defends himself by citing an episode from Thucydides (4.15-22), where the Spartans sent an embassy to Athens and spoke at great length, because the situation required it. The conclusion is that, 
Choricius says, 'I seemed to get my point across to that fellow. He went off nodding his approval and allowed me to bring you the remainder of my oration'. Choricius always has the last word (after all, it is only his words that we have access to), but, tellingly, what seems to win the argument for him is his erudition and inventiveness in answering those who challenge him, as the whole debate is carried out on the level of allusions to classical literature (his detractor brought up Homer; Choricius countered with Thucydides).

Similarly, in Dialexis 8 we learn that Choricius' audience took offence at one of his Homeric quotations. When, in the wedding speech he had delivered for one of his students, the Epithalamium for Zacharias, Choricius compared himself to Eumelus, quoting Iliad 23.536 (where Eumelus is called both last and best), the next day he was accused of self-importance. In this Dialexis he sets forth to defend himself against this charge, pointing out that his reference was only to the fact that he had been late, but also expounding on the Homeric line, and exhibiting his knowledge of other, more appropriate literary figures to whom he would have compared himself, had he really wanted to claim he was the best speaker (the Sirens, Pindar, and Nestor). Choricius, however, is careful not to appear entirely dismissive of his audience's criticism, as he approvingly mentions Plato's words ‘that a few men who are good at listening to orations are more intimidating to a person who comes forward to speak than an ignorant mob of auditors from the agora' (4). ${ }^{31}$ It appears that, although he parades his own learning as superior, Choricius considers (or flatteringly claims to consider) his audience as capable of the kind of learned criticism which could potentially embarrass an orator.

\section{Pacifist oratory?}

While Choricius seems to welcome (and, indeed, actively seeks out, as he says in Dialexis 5) those members of the audience who are knowledgeable enough to challenge his speeches, he repeatedly and vocally expresses his opposition to those whose lack of gentleness and education might actually destabilise Gazan society. Even on the level of literary criticism, Choricius argues that anger and discord have no place in society, and Homer should have thought better before placing the wrath of Achilles right at the beginning of the Iliad. ${ }^{32}$ But, of course, what mostly concerns Choricius are the real threats to the peace and stability of Gazan society: in the Second Panegyric for Marcian, the Bishop is praised for having brought under control some uncouth soldiers stationed near Gaza, as well as those Gazan citizens who were willing to team up with them. 
When the Emperor decided to chastise some rebels by war, the forces which he sent from there had to pass by [here]. They were more tolerable than [regular] soldiers, since they were held in check by imperial orders, but soldiers nevertheless, having coarse minds, tongues which outrun their intelligence, and right hands that outstretched their tongues. Thus, the city was being aroused by fear and disturbed by the announcements from neighbouring cities [...] And some [of the soldiers] were streaming here [into our city] and became bolder towards us than when they had mistreated our neighbours [...] But this noble guardian of our city [Marcian], considering and accomplishing everything which was advantageous, having separated from the inhabitants those whom he saw disposed in a friendly manner toward them [the soldiers] for their own profit, greatly softened their spirit and tamed them. (Laud. Marc. II 23-4)

Conflict resolution skills seem to run in Marcian's family: in the Funeral Oration for Maria, the Bishop's mother, Choricius reports a series of letters sent by Maria to one of her sons, who was a city magistrate, asking him to intervene in the bitter quarrel between two individuals, and 'requesting a settlement advantageous to each of them' (Or. 7.20). ${ }^{33}$ And, while Choricius praises the Saintly Maria for her meekness and simplicity, and implies elsewhere in the oration that she had not received classical education, ${ }^{34}$ it is interesting that her reconciliatory efforts are executed precisely through letters, which, on the one hand, would allow Maria to mediate in a less visible manner, but on the other, presuppose a certain level of formal education and are indicative of the importance of education in the resolution of conflicts. Now, Marcian, who had studied at the Gazan School together with Choricius, and who may even have served as head of the School for a short time after Procopius' death and before Choricius took up that role ${ }^{35}$, was obviously and emphatically an educated man, one whose rhetorical and diplomatic skills could soften spirits, and tame the uncivilised men who have not been touched by paideia. ${ }^{36}$ For this is how the soldiers are represented by Choricius: their minds are unrefined, their tongues outrun their dim intelligence (they speak before they think - the polar opposite of the orator), and their hands outstretch their tongues. $^{37}$

Choricius' disparagement of the martial life has as a consequence that, even when he speaks in praise of military commanders, he is anxious to point out that his honourands are not just capable of martial feats but also of gentleness, mildness, and persuasion. In his Panegyric for 
Aratius and Stephen (the first a military commander, the second a governor), Choricius says that in the case of the two men, the naturally opposite characteristics of high-spiritedness and gentleness are reconciled, so that even within their souls there is no conflict. ${ }^{38}$ In the course of the panegyric, Choricius will praise the commander, Aratius, for dealing with an uprising by the Samaritans without resorting to physical force or the use of arms. ${ }^{39}$ The same theme comes up in his Impromptu Panegyric for Summus, where the general Summus is praised for achieving peace between two enemy tribe leaders not through arrows and spears, but by persuading them to come to an agreement and end their seemingly 'interminable' strife. Choricius underlines that, contrary to the felicitous, permanent outcome brought about through Summus' persuasion, a victory won by arms would only create a very temporary and fragile peace: 'any disagreement would threaten the peace. For whatever is without good will and persuasion is rotten and faulty and fades away after flourishing for a short time' ${ }^{40}$

The importance of rhetoric and persuasion in ending strife and creating peace and stability is brought out in one of Choricius' declamations as well. Declamation 12 is based on an imaginary scenario: we are in an unnamed, fictional city, in which a law stipulates that the citizen who has a brought a war to a successful conclusion can claim for himself whatever prize he pleases. ${ }^{41}$ When this imaginary city was under siege, a professional orator went out alone and convinced the enemy to raise the siege. He now demands the reward that the law guarantees a war hero. He argues against a military man who contested granting the gift to the orator, maintaining that the law implies a hero who won by arms, not one who persuaded the enemy to take off. Choricius sets out in his Protheoria, the explanatory comment which accompanied the published version of the speech, how the speaker will portray his opponent as a stock character from comedy: the boastful soldier. ${ }^{42}$

You can find a model from comedy of how a military man is full of himself and a swaggerer and a great boaster. If any of you remembers Menander's character Tharsonides, he knows what I mean. [...] And 'The Hated One', of course, became the title for the play about Tharsonides. (Protheoria 1)

[The speaker will be] both making fun of the soldier in an ironic way and disparaging him, and treating his irritability as comic and gently deflecting the abuse coming from him. It is appropriate, I think, for him to achieve a characterisation of the opponent as irascible and coarse and to present his own manner as mild and kindly, his professional skill making each appear as such. (Protheoria 8-9) 
Choricius' comments on how the character of the imaginary military man will be constructed reflect his own low opinion of soldiers as uncouth and irascible, ${ }^{43}$ while the orator's mildness and kindness showcase the power of rhetoric to both create and represent such desirable attributes. Choricius admits that he was attracted to the cause of the orator, his fellow practitioner, as he knows more about public speaking than about fighting, ${ }^{44}$ but there are more ways in which Choricius' speaker reflects the opinions and experiences of his author. One of the points he makes against the military man is that, if the enemy had been defeated by force, they would soon take up arms again, because 'hatred festers, and the hostilities grow again from a small incident of strife' (73); however, as the speaker has persuaded them that lifting the siege would be to their own advantage, 'they will not alter what benefits them nor want to bring upon themselves suspicion of dullness of mind by seeming to have raised the siege because taken in by me' (75). The definite, 'once and for all' conclusion of hostilities through diplomacy, as opposed to the fragile nature of military victories, is an argument Choricius himself had used in the Impromptu Panegyric for Summus. Later on, Choricius' speaker rebuffs the accusation of being a coward, which is precisely what Choricius' students had said of him in the incident described in Dialexis 5. Addressing his opponent, the speaker says:

You want yourself to be regarded as a brave fighter, one of the ancient crop of celebrated heroes, while you regard me as both cowardly and timid, the way you people who are practiced in warfare usually belittle those who are continuously trained in speaking. At that moment the orator, trembling at the thought of battles, saved the hero, the soldier. For you were, as it happened, carefully hidden somewhere, but I released both you and the city from the fears that surrounded us. (Declamation 12.107-8)

Throughout the speech a lot of emphasis is placed on the paradoxical nature of the event that saved the city: that the orator 'would go unarmed among heavily equipped enemies, would enter their camp, and would drive them all away by the force of words' (34). In a highly florid speech attributed to the personified enemy city and reserved for the end of the declamation, the orator's victory is presented in terms of almost impossible antithetical pairs: 'One man has prevailed over my whole army, a man untrained in battle defeating a trained force, an unarmed man defeating a heavily armed force' (121). ${ }^{45}$ And while these rhetorical paradoxes would seem to suggest that the heroic performance of the orator, executed solely 
through speaking, should probably belong in the realm of fiction, Choricius' praise of military commanders for achieving lasting peace through diplomacy indicates that the theme of this speech might be closer to Choricius' Gaza than the timeless, non-descript declamatory framework would suggest.

Does this mean that all the opinions expressed by the 'Orator' of Declamation 12 should be attributed to Choricius himself, and would that make him a pacifist? ${ }^{46}$ Although Choricius' comments in the Protheoria, as well as indications within the text, would encourage us to merge author and speaking persona, it should be kept in mind that declamation is a genre which posits an autonomous, imaginary world; the persona of the 'Orator' should, thus, be seen as a fantasy version of the author's self-image, not his exact reflection. When the speaking persona says that, far from being a coward, he is able singlehandedly to save the city, this daydream only partly corrects the stereotype of the 'bookworm' orator as a cowardly man: in real life, it is still military commanders and civic officials who confer and negotiate with enemies. The orator's contribution is that he has taught those military men and officials the skills to argue and persuade, and, perhaps, has instilled in them the values of peace and reconciliation. ${ }^{47}$

Similarly, what is presented in the Declamation as a reality for the speaking persona is not necessarily so for Choricius. The gift which the speaker requests from the city is one that, he claims, will benefit the city by creating more men like himself: 'What then do I seek? That your sons attend my school to be educated as orators rather than soldiers. For I am pained when I see so many young men going on military campaign, whereas the number of those devoting themselves to Hermes and the Muses is small' (Declamation 12.116). The speaker's complaint is attributed by Litsas to Choricius himself, and once turned part of Gaza's reality, it is then explained by the over-recruiting of young men necessary for the military campaigns of Justinian. ${ }^{48}$ While, surely, Choricius would like to see more students enrolling at the Gazan School, it does not necessarily follow from the speaker's statement that the study of rhetoric in Gaza was neglected by young men, in favour of pursuing military careers. Nor can the modern label of 'pacifism' be applied without qualifications to Choricius. While Choricius' ideal city would probably have more orators and fewer soldiers, it is doubtful whether he (or anybody in his time) would seriously argue that all a city needs is orators. 
Choricius' oeuvre poses several restrictions in the attempt to draw definite conclusions about the relationship between town and gown in his contemporary Gaza: the obvious exaggeration of the encomiastic orations, and the fictional background of the declamations impose limits that are difficult to overcome. Our most reliable guide is definitely the Dialexeis, which provide a precious glimpse into Gazan academic life, and seem to portray a peaceful environment, where criticism is welcome, and debates are carried out in a civilised way. Whereas in the Athens of Libanius' time students enrolled to become orators and ended up being trained as soldiers, as Libanius claims, in Choricius' Gaza even military commanders behave as orators, and often rely on their negotiation and reconciliation skills. Choricius' conception of the ideal city, as can be gleaned from both the encomiastic orations and Declamation 12, places a high value on the absence of violence and conflict, and highlights the role of rhetoric in achieving this ideal. A successful orator, such as Choricius' fictional 'Orator' of Declamation 12 or his own teacher Procopius, becomes a prized asset for any city, ${ }^{49}$ while his role and functions in Christian society gradually come to approximate those of the bishop. Notice, for example, how the 'Orator's' feat in confronting the soldiers who threatened his city and convincing them to withdraw is reminiscent of Marcian's 'taming' of the soldiers causing turmoil in Gaza in the Second Panegyric for Marcian. The example of Procopius, said to use his rhetorical skills for the benefit of the weaker members of society, once again shows that an orator was increasingly required to use his speech to alleviate the suffering of others and drive them towards the right path, away from $\sin ^{50}$ The academic gown in late antique Gaza gradually morphs into the cleric's robe, ${ }^{51}$ since both orator and bishop work for the benefit of the city, averting wars and conflicts, and using their classical erudition and rhetoric to extinguish passions ${ }^{52}$.

\section{References}

Abel, F.M. (1931) 'Gaza au VIe siècle d'après le rhéteur Chorikios'. Revue Biblique 40, 531.

Ashkenazi, Y. (2004) 'Sophists and priests in late antique Gaza according to Choricius the rhetor'. In Bitton-Ashkelony, B. and Kofsky, A., eds., Christian Gaza in Late Antiquity. Leiden: Brill, 195-208.

Champion, M. (2014a) “"The Academy and the Lyceum are among us": Plato and the Platonic tradition in the works of Aeneas, Zacharias and Procopius'. In Fowler, R., ed., Plato in the Third Sophistic. Boston and Berlin: Walter de Gruyter, 259-78. 
Champion, M. (2014b) Explaining the Cosmos: Creation and Cultural Interaction in LateAntique Gaza. Oxford: Oxford University Press.

Corcella, A. (2008) 'Coricio di Gaza su retorica e verità (1 Dialexis 4-5)'. Mediterraneo Antico 11, 447-61.

Corcella, A. (2014) 'Serio e giocoso in Coricio di Gaza'. In Amato, E., Thévenet, L. and Ventrella, G., eds., Discorso pubblico e declamazione scolastica a Gaza nella tarda antichità: Coricio di Gaza e la sua opera. Bari: Edizioni di Pagina, 20-31.

Geiger, J. (2014) Hellenism in the East: Studies on Greek Intellectuals in Palestine. Stuttgart: Franz Steiner.

Gleason, M. (1995) Making Men: Sophists and Self-Presentation in Ancient Rome. Princeton: Princeton University Press.

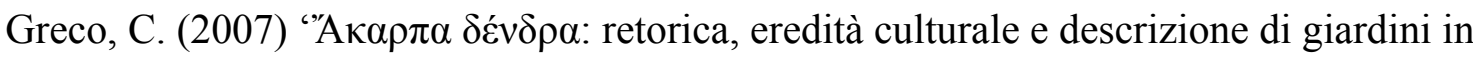
Coricio Gazeo'. Medioevo Greco 7, 97-117.

Greco, C., ed. (2010) Coricio di Gaza, Due orazioni funebri: (orr. VII-VIII Foerster, Richtsteig). Alessandria: Edizioni dell'Orso.

Greco, C. (2011) 'Late antique portraits: reading Choricius of Gaza's encomiastic orations (IVIII F.-R.)’. Wiener Studien 124, 95-116.

Greco, C. (2014) 'Choricius on literature: a study of Platonic vocabulary referring to literary creation'. In Fowler, R., ed., Plato in the Third Sophistic. Boston and Berlin: Walter de Gruyter, 239-57.

Gunderson, E. (2000) Staging Masculinity: The Rhetoric of Performance in the Roman World. Ann Arbor: University of Michigan Press.

Gunderson, E. (2003) Declamation, Paternity, and Roman Identity: Authority and the Rhetorical Self. Cambridge: Cambridge University Press.

Hadjittofi, F. (2014) 'Centring Constantinople in Himerios' Oratio 41'. In de Francisco Heredero, A., Hernández de la Fuente, D. and Torres Prieto, S., eds., New Perspectives on Late Antiquity in the Eastern Roman Empire. Newcastle upon Tyne: Cambridge Scholars Publishing, 230-44.

Hadjittofi, F. (2016) 'Cross-dressing in the Declamations of Choricius of Gaza'. In Poignault, R. and Schneider, C., eds., Fabrique de la declamation antique, Lyon: Maison de l'Orient et de la Méditerranée, 353-71

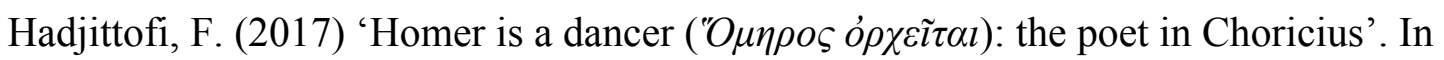
Lauritzen, D., Amato, E. and Corcella, A., eds., L'École de Gaza: Espace littéraire et identité culturelle dans l'Antiquité tardive. Leuven: Peeters, 151-62.. 
Harris, W. (2001) Restraining Rage: The Ideology of Anger Control in Classical Antiquity. Cambridge, MA: Harvard University Press.

Kalimtzis, K. (2012) Taming Anger: The Hellenic Approach to the Limitations of Reason. London: Bristol Classical Press.

Litsas, F. (1981) Choricius of Gaza: An Approach to his Work. Diss. Chicago.

Litsas, F. (1982) 'Choricius of Gaza and his descriptions of festivals at Gaza'. Jahrbuch der Österreichischen Byzantinistik 32(3), 427-36.

Lupi, S. (2014) 'Occasione e performance nelle declamazioni di Coricio di Gaza'. In Amato, E., Thévenet, L. and Ventrella, G., eds., Discorso pubblico e declamazione scolastica a Gaza nella tarda antichità: Coricio di Gaza e la sua opera. Bari: Edizioni di Pagina, 219.

Mango, C. (1972) The Art of the Byzantine Empire 312-1453. Englewood Cliffs, NJ: Prentice-Hall.

Manzione, C. (2014) 'Per un'introduzione al Rhetor di Coricio di Gaza (op. XLII [decl. 12] F./R.)'. In Amato, E., Thévenet, L. and Ventrella, G., eds., Discorso pubblico e declamazione scolastica a Gaza nella tarda antichità: Coricio di Gaza e la sua opera. Bari: Edizioni di Pagina, 170-203.

Penella, R. (2007) Man and the Word: The Orations of Himerius. Berkeley and London: University of California Press.

Penella, R., ed. (2009) Rhetorical Exercises from Late Antiquity: A Translation of Choricius of Gaza's Preliminary Talks and Declamations. Cambridge: Cambridge University Press.

Penella, R. (2011) 'Menelaus, Odysseus, and the limits of eloquence in Libanius, Declamations 3 and 4'. In Lagacherie, O. and Malosse P.-L., eds., Libanios, le premier humaniste. Études en hommage à Bernard Schouler (Actes du colloque de Montpellier, 18-20 mars 2010). Cardo, 9. Alessandria: Edizioni dell'Orso, 93-105.

Pernot, L. (1993) La rhétorique de l'éloge dans le monde gréco-romain. Paris: Institut d'Études Augustiniennes.

Polański, T. (2011) 'The mosaic and painting decoration in the church of Saint Stephen of Gaza and the Christian ecphrasis (Choricius of Gaza, Asterius of Amaseia, Nilus of Sinai)'. Folia Orientalia 48, 183-210.

Russell, D. (1983) Greek Declamation. Cambridge: Cambridge University Press.

Quiroga, A. (2007) 'From Sophistopolis to Episcopolis: The case for a third sophistic'. Journal for Late Antique Religion and Culture 1, 31-42. 
Saliou, C. (2005) 'L'orateur et la ville: réflexions sur l'apport de Chorikios à la connaissance de l'histoire et de l'espace urbain de Gaza'. In Saliou, C., ed., Gaza dans l'Antiquité Tardive: Archéologie, rhétorique et histoire, Actes du colloque international de Poitiers (6-7 mai 2004). Salerno: Helios, 171-95.

Schouler, B. (2005) 'Chorikios déclamateur'. In Saliou, C., ed., Gaza dans l'Antiquité Tardive: Archéologie, rhétorique et histoire, Actes du colloque international de Poitiers (6-7 mai 2004). Salerno: Helios, 117-34.

Sorabji, R. (2000) Emotion and Peace of Mind: From Stoic Agitation to Christian Temptation. Oxford: Oxford University Press.

Stenger, J. (2010) 'Chorikios und die Ekphrasis der Stephanoskirche von Gaza: Bildung und Christentum im städtischen Kontext'. Jahrbuch für Antike und Christentum 53, 81-103.

Telesca, C. (2011-2012) 'Sull'ordine e la composizione del corpus di Coricio di Gaza'. Revue des études tardo-antiques 1, 85-109.

Tomassi, G. (2015) 'Tyrants and tyrannicides: between literary creation and contemporary reality in Greek declamation'. In Amato, E., Citti, F. and Huelsenbeck, B., eds., Law and Ethics in Greek and Roman Declamation. Berlin: Walter de Gruyter, 249-68.

Van Hoof, L. (2010) 'Greek rhetoric and the later Roman Empire: the bubble of the "Third Sophistic"'. Antiquité Tardive 18, 211-24.

Ventrella, G. (2014) 'Da Dione Crisostomo a Coricio: il motivo dell'artista alla sbarra a Gaza fra tradizione retorica e nuove istanze religiose'. In Amato, E., Thévenet, L. and Ventrella, G., eds., Discorso pubblico e declamazione scolastica a Gaza nella tarda antichità: Coricio di Gaza e la sua opera. Bari: Edizioni di Pagina, 45-74.

Walmsley, A. (1996) 'Byzantine Palestine and Arabia: urban prosperity in late antiquity'. In Christie, N. and Loseby, S.T., eds., Towns in Transition: Urban Evolution in Late Antiquity and the Early Middle Ages. Aldershot: Scolar Press, 126-58.

Watts, E. (2005) 'The student self in late antiquity'. In Brakke, D., Satlow, M. and Weitzman, S., eds., Religion and the Self in Antiquity. Bloomington and Indianapolis: Indiana University Press, 234-51.

Watts, E. (2006) City and School in Late Antique Athens and Alexandria. Berkeley and London: University of California Press.

Webb, R. (2006) 'Rhetorical and theatrical fictions in the works of Choricius of Gaza'. In Johnson, S., ed., Greek Literature in Late Antiquity: Dynamism, Didacticism, Classicism. Aldershot: Ashgate, 107-24.

Weiss, Z. (2014) Public Spectacles in Roman and Late Antique Palestine. Cambridge, MA. 


\title{
Westberg, D. (2010) Celebrating with Words: Studies in the Rhetorical Works of the Gaza
}

\author{
School. Diss. Uppsala.
}

1 This is not to say, of course, that the declamations were only performed in a school setting; in fact, there are indications that at least some of these speeches were delivered in front of a wider audience; see n. 29 below. On the performance context of the declamations see most recently Lupi (2014). As for the Defence of the Mimes, a text which apparently fits into neither of these categories, I agree with Westberg $(2010,142)$ in considering it a quasi-declamatory exercise. Translations of Choricius used in this chapter will be taken (and occasionally adapted) from Penella (2009) for the declamations and preliminary talks and Litsas (1981) for the encomiastic orations.

2 For two early examples see Abel (1931) and Litsas (1982).

3 Penella $(2009,1-8)$ highlights the timeless quality of the declamations, and concomitantly underplays their relevance for their contemporary context (1: 'we might plausibly imagine them to have been composed in any century of the Roman Empire from the time of Augustus on'; 8: 'have no connection in theme with the real world that their author inhabited'). On the contrary, Greek and Roman declamation of the early Imperial period has often been read in connection to its historical context and its importance for the formation of an elite masculine ideal; see, e.g., Gleason (1995), Gunderson (2000) and (2003). Historicising readings of Choricius' declamations are all very recent: see Ventrella (2014), Tomassi (2015), and Hadjittofi (2016).

4 The term 'Third Sophistic', coined by Pernot (1993, 14 n. 9) to describe the renascence of Greek rhetoric in late antiquity, has recently come under criticism; see the discussions in Quiroga (2007) and Van Hoof (2010). 5 For Choricius as a literary artist see Webb (2006), Greco (2007) and (2014), and Hadjittofi (2017). 6 Schouler $(2005,117)$, and Manzione $(2014,195-6)$ point out that the majority of Choricius' declamations have war as their background, which could be indicative of the absence of peace in the Gazans' daily lives. Greco's (2011) study of Choricius' encomiastic orations concludes that the values praised are those of peace, harmony, and order, 'the greatest expectations of any troubled society' (116). For a representation of Gaza as a society in turmoil and plagued by religious conflict see the Vita Porphyrii, whose fictitious date, however, is the fifth century CE. On the other hand, Walmsley's (1996) historical and archaeological overview suggests a surprising level of stability and urban affluence in the cities of Palestine and Arabia between the fourth and sixth centuries.

7 See, e.g., Mango (1972, 60-72), Saliou (2005), Stenger (2010), and Polański (2011).

8 For the specific dates see Saliou $(2005,172)$. The two Orations are henceforth abbreviated as Laud. Marc. I and Laud. Marc. II.

9 See Jacobs (in this volume) on the transformation of the built cityscape in late antiquity.

10 Choricius mentions explicitly, in Laud. Marc. I 16, the future readers who will have access to his text but will not have seen the church he is about to describe. Greco $(2011,99-101)$ discusses this passage and its Platonic undertones. Choricius is also explicit about the power of his words to 'build' the church of St Stephen: in Laud. Marc. II 59 he declares that the church is also 'constructed' by him, 'not by means of stone and wood, but through those things that we know how to work'. On the orator's metaliterary claim on the power and authority of his words see Hadjittofi (2017).

11 Ashkenazi $(2004,207)$ argues for the harmonious coexistence in Gaza of 'sophists and priests, Hellenistic heritage and Christian devotion'. For a significant revision of this picture see Stenger (2010), who suggests that Choricius has to tiptoe around the Christian sensitivities of his audience, and that he avoids calling for an unqualified acceptance of classical myths and paideia.

12 On the civic patriotism of intellectuals from late antique Syrian and Palestinian cities, and how this was expressed in terms of competitive Hellenism, see Geiger $(2014,58)$. For Aeneas of Gaza's assertion that 'the Academy and the Lyceum are among us' (in Ep. 18.8-9) see, most recently, Champion (2014a), who uses this quote in the title of his article, as well as Stenger in this volume. For a detailed analysis of the Gazan thinkers' confident transformation (and adaptation to Christian standards) of classical philosophy see Champion (2014b). 13 This is not actually as surprising as it might seem: late antique orators do not shrink from proclaiming as superior to Athens the contemporary cities which they praise; for an example see Himerius' encomium of Constantinople in Or. 41.3, with the comments in Hadjittofi (2014, 236-7).

14 I have adapted Penella's translation to reflect the emendations of the Greek text suggested by Corcella (2008, $450)$, which I find convincing. Corcella $(2014,20-1)$ revisits this passage, with further comments on Gaza's Überbietung of Athens and the combination of seriousness and playfulness in its cultural life.

15 For a prime manifestation of this theme in a Christian author see Basil of Caesarea's address 'To young men, on how they might derive profit from pagan literature' (especially paragraph 4). The idea is not exclusively Christian, however, as precedents can be found in pagan moralising texts, such as in Plutarch's 'On how a 
young man should study poems' (Moralia 14.12). In the First Panegyric for Marcian, Choricius' praise of the Bishop's education highlights his discernment in reading classical literature: 'while still a young man he culled the most beautiful things from the poetic [Muse], gathering on the one hand whatever was useful, and smiling on the other hand at the stories, believing that they had been made by the Homerids for profitless merriment' (Laud. Marc. I 6). For a nuanced analysis of this passage see Greco (2007, 109-17).

16 This does not necessarily detract from the admiration Choricius expresses for Athenian festivals elsewhere: in Dialexis 22.4, for example, he approvingly mentions an 'Attic' annual festival, in which orators gave rhetorical displays and actors put on ancient plays before an audience very 'fond of listening', to whom the Gazan audience is implicitly compared. In this passage, Choricius claims that his Attic paideia compels him to observe Attic practice. For the Gazan audience's ‘big appetite for oratory' see Dialexis 9.1. For Choricius' education under Procopius as taking place 'in Attic meadows' see the Funeral Oration for Procopius (8.1.1). 17 The idea that a man's character can be entirely independent from his outward appearance (and especially his clothing) is recurrent in Choricius (it appears in Declamations 3 and 11, as well as the Defence of the Mimes), and might have something to do with certain strands of Christian ideology, expressed mostly in popular stories about Saints and martyrs, which dismiss dress as a as reliable indicator for the condition of the inner self; see Hadjittofi (2016).

18 Corcella $(2014,28-9)$ points out that it is strange for Choricius, the author of the Defence of the Mimes, to speak against dancing and Dionysiac performances, and suggests that this Oration must have been delivered at a time when civic authorities (maybe even Marcian himself) had intervened to suppress some such spectacles, perhaps pantomimes (a genre more closely linked with dancing than the mime, which Choricius had 'defended'). On the important place of spectacles in the social life of late antique Gaza see most recently Weiss $(2014,230-5)$.

19 For the increasing emphasis on anger control in both Greek and Roman philosophical discourses see Harris (2004). For the Church Fathers' condemnation of anger as sinful see Sorabji (2000, 391-3) and Kalimtzis (2012, 143-50). Gregory of Nyssa, for example, states that indignation and anger must 'be as watch-dogs to be roused only against attacking sins' (On Virginity 18.3).

20 See Watts $(2006,25$ and 42-6), who notes that, even though ' $[\mathrm{b}] \mathrm{y}$ the end of the fourth century, student violence had become a major problem in educational centres throughout the empire', the situation in Athens was uniquely grave, forcing teachers, even those who held publicly funded positions, to teach in their own homes (43).

21 Student violence and other deviant behaviour was acceptable (and even honourable) in certain contexts, and, as Watts $(2005,237)$ puts it, 'students arrived at school expecting to live according to a different set of values', which would integrate them in the scholastic group - seen as largely independent from the rest of society and governed by its own set of rules. Libanius himself admits that he was expecting to take part in violent activities and blow all his money away (Or. 1.19).

22 In Or. 1.16 and 20 Libanius recounts how he was kidnapped at the quayside, got cooped up in a cell about as big as a barrel, was not allowed even to catch a glimpse of the teacher he had wanted to study with (Epiphanius), and was forced to enrol under Diophantus, whom he clearly wanted nothing to do with.

23 See $O r .16$ 'From the extempore oration given when discord arose within his school', Or. 65, addressed 'To those involved $<$ in $>$ a conflict and absent from a lecture', Or. 21 'To the newly enrolled Severus who had turned his attention to a conflict', and Or. 66 'An extempore speech to some students who seemed to be rebellious'. Or. 69, a 'Discourse delivered after his wound healed' implies that Himerius was physically attacked by his envious enemies (69.2: 'envy's fight against eloquence'). These speeches are translated by Penella (2007) in a chapter titled 'In and Around Himerius' School'.

24 On Himerius' awareness of the social and political value of his speech see Hadjittofi (2014, 243-4). By contrast, Libanius' Declamations 3 and 4 (featuring Menelaus and Odysseus as speakers arguing for the return of Helen) suggest that, on the one hand, speech has some potential to resolve conflict, but on the other, given the audience's knowledge of the ultimate failure of both speeches, this potential is severely limited; see Penella (2011).

25 On the authenticity and place of the Dialexeis within the Chorician corpus see Telesca (2011-2012, 89-93 and 97-100). On the information they provide regarding the performance of Choricius' declamations see Lupi (2014).

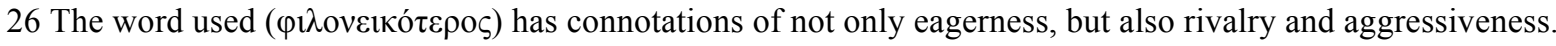
Words from the same root are used for the two individuals quarrelling in $O r$. 7.20, to be discussed below (

27 This 'preliminary talk' introduces Declamation 1.

28 Dialexis 16 corroborates this point, as it mentions and answers his students' persistent requests that he declaimed more often. 
29 The evidence of this Dialexis, therefore, suggests a public performance of Declamation 8. On the likely composition of the 'crowd' (ő $\chi \lambda \mathrm{o} \varsigma)$ see Lupi $(2014,14-5)$.

30 The reference is to Iliad 3.214-5. Dialexis 23, delivered before the second half of Declamation 10

('Patroclus'), also addresses a member of the audience who had criticised Choricius for the length of his speech. 31 See Pl. Symp. 194b6-8.

32 Or. 13.4: 'I wish that discord would disappear from among the gods and from among men, and I blame the poet [Homer] that he neglected this, and that he described in the prelude of his poem [the Iliad] the wrath of Achilles, although I see that sometimes it [wrath] can become the motivation for good things'. Cf. Greco (2014, 243 n. 22). For Christian attitudes towards anger see above, n. 19.

33 I thank Jan Stenger for reminding me of this passage.

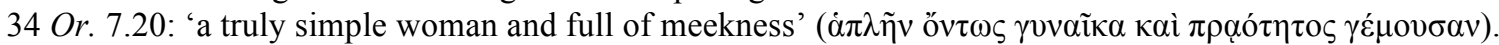
Earlier in the speech, in paragraph 4, Choricius says that Maria embodied the ideal of womanhood as presented by Sophocles, although, of course, she had not read Sophocles.

35 See Litsas $(1981,12)$, based on an admittedly vague reference in the Funeral Oration for Procopius 50. 36 For Choricius' portrayal of Marcian as a man well versed in classical literature see Greco (2011, 100-3). 37 'Their hands outstretching their tongues' is most probably a reference to plundering ('taking before they ask'), but could conceivably be interpreted in a more general way, as taking action before any discussion or consultation.

38 Or 3.8: 'Yet, it seems to be natural that gentleness and spirit contradict each other, so that even Socrates is, I think, clearly puzzled as to where he might find a character which is at the same time mild and magnanimous, because it is naturally difficult for the one to coincide with the other. But in your case, both of them dissolve their quarrel and are reconciled'. The 'you' here is plural, and refers to both men.

39 Or 3.13, on which see Westberg's article in this volume.

40 Or. 4.19. Westberg (2010, 71-6) analyses these two speeches together under the telling title 'Give peace a chance: Choricius' redefinitions of war and courage'.

41 Russell $(1983,22)$ calls the imaginary city which provides the background for many Greek declamations 'Sophistopolis', and points out that this city bears some resemblance to classical Athens: it 'is a democracy, where the rhetor - both political and expert in oratory - is something of a hero'; this observation is especially relevant here. The law on the war hero's prize is not historical, but appears in Choricius' Declamations 5, 11, and 12, and with a variation (referring to a tyrannicide instead of a war hero) in Declamation 7. On this theme in Choricius and in other authors, both Greek and Roman, see Manzione (2014, 182-95).

42 On the authenticity of the Protheoriae see Penella (2009, 16 n. 71), with whom I agree that the personal nature of the remarks would make any possible frauds (which I do not consider likely) very disappointing. 43 Cf. Dialexis 9.3-4, where the god of war himself, Ares, is ridiculed by Choricius as unattractive, arrogant, and always frowning; even if he tried to smile at his beloved, Aphrodite, his smile would terrify rather than delight her.

44 See Protheoria 5.

$45 \mathrm{Cf}$. the equally florid speech which the speaker attributes to the enemies' women: 'They came home because of what an enemy agent advised; they came home in numbers, having fled from one man; they came home fully armed, running away from an orator!' (65).

46 Manzione $(2014,196)$ proclaims Choricius a pacifist, following Schouler $(2005,132-3)$, but adding a Christian angle, attributing Choricius' anti-war mentality to his 'adesione allo spirito e al messaggio cristiano'. 47 For the connections between Summus and the Gazan School see Greco (2014, 243 n. 22), with further references.

48 See Litsas $(1981,22)$.

49 Choricius says that many cities vied for Procopius, his rhetorical skills arousing 'passionate competition among the greatest cities that desire literary activities'; see the Funeral Oration for Procopius 12.

50 See the Funeral Oration for Procopius 22, with Westberg $(2010,110)$ and Greco's (2010) commentary ad loc. 'Many did not perceive the anguish of being orphans; to many women widowhood seemed a light thing because he alleviated their suffering. He was never defeated in the fight against some vile passion, indeed, he convinced many of those who were attached to unnatural desires to repent'. Westberg (2010, 111 and 133-4) also points out the similarities between the functions of the orator and the mime, a topic too rich to be treated here, although it is relevant for this discussion that Choricius envisions the mime as providing relief from the stress and discord present in everyday life as well as in other spectacles.

51 According to the Funeral Oration for Procopius 21, Procopius was a 'priest in everything but the $\sigma \chi \tilde{\eta} \mu \alpha$ (schêma)' - a word which can refer to the priest's characteristic dress or to being ordained; see Greco's (2010) commentary ad loc.

${ }^{52}$ I am grateful to Jan Stenger for inviting me to participate in this exciting project and to David Westberg for sending me his $\mathrm{PhD}$ thesis on the Gazan orators. 